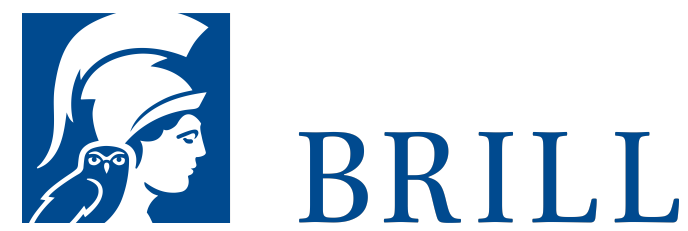

\title{
Aggadat Bereshit
}

Translated from the Hebrew with an Introduction and Notes

Author: Lieve Teugels

Aggadat Bereshit is a homiletic Midrash on the Book of Genesis written in Hebrew, about the 1oth century CE. It has a unique threefold structure, dividing the chapters or homilies according to the three parts of Tenakh: Torah (Genesis), Prophets and Writings. It contains interesting material, some unparalleled in rabbinic literature, such as an anti-Christian interpretation of Genesis 22. Besides being the first translation, this volume presents some variants from manuscripts unknown by its last editor (S. Buber, Krakow 1903). This English translation will be welcomed in the world of Jewish and Biblical Studies, academics as well as lay-persons with lesser knowledge of rabbinic Hebrew. The extensive introduction gives an up-todate overview of the questions as to text, contents, structure, dating and provenance of this hitherto neglected Midrash.

Readership

Academic libraries, educated laymen, institutes, researchers, students

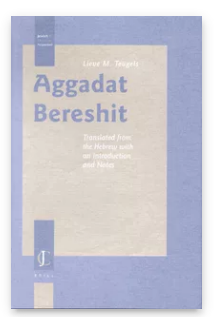

Pages: xxxvi, 306 pp.

Language:

English

Subjects:

General, Jewish

Studies

Publisher: Brill

Series:

Jewish and

Christian

Perspectives

Series, Volume: 4

E-Book (PDF)

Released online:

29Jan 2020

ISBN: 978-90-

04-42141-7

List price

USD \$161.oo

Hardback

Publication date: 26 Sep 2001

ISBN: 978-90-

04-12173-7

List price

USD \$161.0o 
Biographical Note

LieveTeugels, Doctor in Theology, is Lecturer in Jewish Studies (Utrecht University). She has written The Background of the Anti-Christian Polemics in Aggadat Bereshit (1999) and Aggadat Bereshit and the Triennial Lectionary Cycle, (2000).

For more information see brill.com

\begin{abstract}
Order information: Order online at brill.com +44330 333 0049 | customerservices@brill.com Submission information: brill.com/authors
\end{abstract}

Titles published by Brill | Fink, Brill | mentis or Brill | Schöningh: +49(o)71 5413279216 | brill@brocom.de 